2. Васильєв Є. Сучасна драматургія: жанрові трансформації, модифікації, новації. Луцьк: Твердиня, 2017. 532 с.

3. Верещак Я. Пекельна дорога до раю: Маленька п'єса про великий український сюр. Верещак Я. Центрифуга. Варіанти. Збірка п’єс. К.: НЦТМ ім. Л.Курбаса, 2018. С. 65-84.

4. Вісич О. Метадрама: теорія і репрезентація в українській літературі. Луцьк: Вежа-друк, 2018. 340 с.

5. Діброва В. Куліш. П'єса на дві дії. К.: Видавництво «Український пріоритет», 2019.96 с.

6. Гундарс Л. Драматика, или Поэтика рациональности: пер. с латыш. М: Манн, Иванов и Фербер, 2020. 224 с.

7. Миколайчук-Низовець О. Гайдамаки. Інші. Миколайчук-Низовець О. Алхімія часу: Зб. драматургічних творів. К.: Світ знань, 2019. C. 173-216.

8. Паві П. Словник театру. Львів: Видавничий центр ЛНУ імені Івана Франка, 2006. 640 с.

DOI https://doi.org/10.30525/978-9934-26-110-7-48

\title{
АРХЕТИПИЧЕСКИЙ МОТИВ КАК СПОСОБ ПСИХОЛОГИЗАЦИИ ХУДОЖЕСТВЕННОГО ПРОИЗВЕДЕНИЯ (НА ПРИМЕРЕ РОМАНА ДЖ. ХАРРИС «ПЯТЬ ЧЕТВЕРТИНОК АПЕЛЬСИНА»)
}

\author{
Храбан Т. Е. \\ кандидат филологических наук, \\ заведующая кафедрой иностранных языков \\ Военный институт телекоммуникаиий и информатизации \\ Кодола Р. Н. \\ преподаватель кафедры иностранных языков \\ Военный институт телекоммуникаций и информатизации \\ г. Киев, Украина
}

Психолингвистика оказывает значительное влияние на исследования в области художественной литературы. Так, при изучении специфики произведения в центре внимания исследователя часто оказывается изображение внутреннего мира героя, иными словами, психологизм худо- 
жественной литературы. В данной статье психологизм рассматривается как доминанта психологического текста, который создается автором с целью раскрытия внутреннего мира человека, его мыслей, чувств, ощущений, и в котором акцент ставится на неповторимую в своей индивидуальности психологию личности. Психологизм проявляется прежде всего в повествовательных структурах произведения: в изменении взаимосвязей повествовательных интроспекций и ретроспекций, композиционных приемах психологизма, эволюции баланса внутреннего и внешнего воспроизведения, описания и изображения, в общих (типологических) и национально-литературных изменениях в конструировании характера, которые происходят за счет увеличения веса психологического анализа - основного элемента психологизма как художественной системы, изменений его качества, детализации, уточнения и интенсификации художественно фиксирующих психологических процессов [1, с. 11]. Каждый автор использует целый арсенал литературных художественных средств психологизации своих произведений, который может проявляться на всех уровнях художественного текста нарративной, композиционной, время-пространственной и образной. Спецификой романа Джоанн Харрис «Пять четвертинок апельсина» является выработка собственного стиля психологизации, суть которого состоит в формирования архетипических мотивов «драконоборство» [2, с. 69] и «сделка с дьяволом». Эти мотивы в романе тесно переплетены и действуют (с той или иной степенью интенсивности) взаимосвязано, одновременно, «формируя различные психические содержания» [3]. Несмотря на то, что в романе «трансформации традиционных сюжетов или дробление традиционных сюжетов на своеобразные осколки все больше затемняют глубинные архетипические значения» [2, с. 69]: «герой» заменяется девятилетней девочкой по имени Фрамбуаза, а «дьявол/дракон» - щукой, первичный архетип, лежащий на глубинном уровне повествования, достаточно ясно проглядывается. Архетипический мотив «драконоборство» связывается в романе со смертью: девочка, живущая по соседству с Фрамбуазой, была укушена змеей и умерла. Фрамбуаза внезапно осознает, что она тоже смертна, ее охватывает ужас. Существование в постоянной тревоге мучительно для девочки, поэтому смерть, будучи неизвестной, «наделяется собственным культурно-индивидуально-религиозно-мистическим содержанием» [4, с. 358] - Фрамбуаза пытается опредметить страх смерти, связать его с чем-то конкретным во внешнем мире. «В мифологическом измерении смерть приобретает образ некого существа: старухи с косой, скелета. Так, страх смерти дробится и воплощается в страхах перед 
чем-то потенциально опасным и угрожающим, а также тем, что ассоциируется со смертью. Это в отличии от смерти, имеет материальное воплощение, становится тем, чего можно избегать» [4, с. 358]. Таким материальным воплощением смерти для Фрамбуазы становится старая щука, которая, согласно местной легенде, живет в реке. Человека, который увидел щуку, но не смог ее поймать, ждет несчастье срабатывает проклятье этого мифического существа - Старой Матери, как называют ее в деревне. Местные жители считают, что это - призракубийца, который ненавидит людей. Постоянно ощущая острый ужас смерти, Фрамбуаза выбирает стратегию психологической защиты против непереносимых мыслей и состояний - веру в собственную исключительность: девочка убеждена, что она сможет поймать щукумонстра. Таким образом, в романе реализуется важнейший архетипический мотив активного противостояния героя неким представителям демонического мира. Архетипический мотив «драконоборство» в контексте преодоления страха смерти дает писательнице возможность объяснить систему жизненных ценностей личности и дать описательную характеристику наиболее стержневой смысловой системы, ответственной за общую направленность жизни подростка. В романе переживание страха смерти девочкой выводится на уровень личностного смысла и выступает как ценностно-смысловая сфера в определении приоритетов индивидуальной жизненной стратегии - одержать победу. Выбранная стратегия психологической защиты против страха смерти определяет поведенческую, эмоциональную и когнитивную сферы подростка, их основной характеристикой становится конфронтация. В поведении Фрамбуазы наблюдается импульсивная активность с целью попытаться хоть как-то повлиять на ситуацию. В эмоциях Фрамбуазы преобладают стенические эмоции (агрессивность, злость и досада). В когнитивной сфере - аффективная захваченность ситуацией. Как видим, Дж. Харрис наделяет Фрамбуазу тем неистовым и строптивым характером, который является составной частью архетипического образа героя. Факт, что образ героя воплощен в девятилетнюю девочку, свидетельствует о своеобразной авторской ревизии архетипа героя, а использование в романе архетипического мотива «драконоборство» стает тем стилистическим приемом, с помощью которого раскрывается психология главной героини как представителя сенситизирующего стиля преодоления стресса, для которого характерна эмоциональная Я-концепция [5]. Архетип героя в динамике неотделим от того, что можно было бы назвать «испытанием». В романе сюжетное разрастание в плане синтагматического развертывания ядерного образо- 
вания «любовь» осуществляется Дж. Харрис таким механизмом как драматизация. Поэтому не случаен интерес писательницы к архетипическому мотиву «договор с дьяволом». С позиции психологии «договор с дьяволом» представляет собой интрапсихическую защитную стратегию «сделка с судьбой» (англ. bargain with fate) [6], которую использует Фрамбуаза. Этот вид сделки с судьбой широко распространен и разнообразен. Хотя это часто является частью частной религии, она также является характерной чертой многих признанных религий и фигурирует в произведениях от Библии до современной художественной литературы. Сделка будет варьироваться в зависимости от оборонительной стратегии, из которой она исходит (самоуничижение, нарциссизм, перфекционизм, высокомерная мстительность, отставка), каждая из которых порождает сделки, отражающие его взгляд на мир и его систему ценностей [7]. Подчиняясь своему внутреннему диктату, девочка пытается волшебным образом воздействовать на внешнюю реальность. Она не рассматривает свои требования как нечто непомерное, а только как то, чего она вправе ожидать, принимая во внимание ее решение поймать речного монстра. Дж. Харрис изображает в своем романе как реализуется эта сделка, хотя по высокой цене: Фрамбуаза загадывает желание, чтобы ее друг Томас навсегда остался в деревне. И это желание сбывается: Томас, пытаясь помочь девочке вытащить громадную рыбу на берег, тонет в реке. Фрамбуаза могла бы уберечь Томаса, но любовь девочки затемняется амбициями и стремлением к «мстительному триумфу». Она живет «днем расплаты», когда она докажет свое превосходство, унизит своих врагов и покажет, как ее обидели, то есть условия сделки были определены не внешними силами, а требованиями преобладающей психологической оборонительной стратегии главной героини.

Таким образом, роман Дж. Харрис «Пять четвертинок апельсина» насыщен архетипическими образами, внутренняя структура которых обусловлена «скрытыми» архетипами. Спецификой творчества Дж. Харрис является выработка собственного стиля психологизации: осознание главной героини романа себя, своего «я», оценка себя и окружающего мира, построение концептуальной картины мира раскрывается писательницей через введение в сюжетную линию романа архетипических мотивов. Архетипические мотивы «драконоборство» и «сделка с дьяволом» внутренне логичны и распознаваемы. Вместе с тем, они обогащаются разнообразным образным, сюжетным содержанием, вследствие чего приобретают новые актуальные формы. 


\section{Литература:}

1. Проскурнин Б. Художественный психологизм до и после Фрейда. Филологический заметки. 2008. № 1. С. 5-17.

2. Мелетинский Е.M. О литературных архетипах. Москва: Российский государственный гуманитарный университет, 1994. URL: http://ivgi.rsuh.ru/binary/object_2.1337777427.23922.pdf.

3. Юнг К.Г. Архетип и символ. М.: Канон+РООИ "Реабилитация", 2016. URL: https://bookap.info > psyanaliz > yung_arhetip_i_simvol.

4. Звонарева Ю.И. Проблема исследования страха смерти в философии и психологии. Психологический вестник Уральского государственного университета. 2009. № 7. С. 35-36.

5. Glazer S, Liu C. Work, Stress, Coping, and Stress Management. Oxford Research Encyclopedia of Psychology. Oxford, 2017. DOI: 10.1093/acrefore/9780190236557.013.30.

6. Little A., Zeitzoff T. A Bargaining Theory of Conflict with Evolutionary Preferences. International Organization. 2017. № 71(3). P. 523-557. DOI: $10.1017 /$ S0020818317000182.

7. Paris B.J. A Psychological Approach to Fiction Studies in Thackeray, Stendhal, George Eliot, Dostoevsky, and Conrad. New York: Routledge, 2017. DOI: https://doi.org/10.4324/9781315083261. 